\title{
Obstacles to Education of the Children of Refugees and IDP: Lessons and Policy Options from the European Union's 'Education for Life' Project in Uganda and South Sudan
}

\author{
Steve Nwokeocha
}

\section{ABSTRACT}

\begin{abstract}
The study documented the obstacles to the education of the children of refugees and internally displaced people (IDP), especially in the wake of the COVID-19 pandemic and policy options. While it reviewed the global situation, it substantially reported the experiences of the European Union's Education for Life Project which provided Accelerated Education Programme (AEP) for the children of refugees and IDP in Uganda and South Sudan. It gathered data from three keys sources: UNHCR and related literature; reports of the Education for Life Project; and Focused Group Discussion (FGD) with key officials of the Project. It revealed the existence of 79.5 million people displaced world-wide (which include 26 million refugees and 45.7 million IDPs). About 7.1 million children of the refugees and IDP are of schooling age with only 3.4 million accessing education. Relying on the United Nations [1] Resilience Framework, the study recommended policies to ensure that the learners, teachers, and education system have the capacity to withstand the COVID-19 pandemic and future emergencies.
\end{abstract}

Keywords: Education for Life Project, Education of Children of Refugees and IDP, Learning under COVID-19 pandemic, South Sudan, and Uganda.
Published Online: July 28, 2021

ISSN: $2736-4534$

DOI : $10.24018 /$ ejedu.2021.2.3.138

Steve Nwokeocha *

University of Calabar, Calabar, Nigeria. (e-mail: drsteve44@gmail.com)

*Corresponding Author

\section{INTRODUCTION}

UNHCR [2] defines refugees as "people who have fled war, violence, conflict or persecution and have crossed an international border to find safety in another country." On the other hand, Internally Displaced Persons (IDPs) "have not crossed a border to find safety. Unlike refugees, they are on the run at home. IDPs stay within their own country and remain under the protection of its government, even if that government is the reason for their displacement" [3]. Often IDPs move to places that are extremely difficult for humanitarian services to access. Thus, they are among the world's most vulnerable persons [3].

The world is increasingly crisis-ridden. By the weeks and months, peoples' lives are profoundly disrupted by conflicts and in some cases natural catastrophes - for instance, UNHCR [4] reports about the massive flood which is negatively impacting thousands of refugees and IDPs in Sudan. In 2018, UNHCR [5] revealed that by 2017 there were 68.5 million persons "forcibly displaced" worldwide. Of this number, 25.4 million were refugees, 40 million internally displaced, and 3.1 million asylum seekers. Of the 25.4 million refugees, 19,941,300 were under the UNHCR mandate (Table I). It also stated that 44,400 persons are displaced everyday while in 2017 alone 16.2 million persons were displaced. It is not surprising, therefore, that Filippo Grandi, United Nations High Commissioner for Refugees, declared that "we are at a watershed, where success in managing forced displacement globally requires a new and far more comprehensive approach so that countries and communities aren't left dealing with this alone" [5]. By the end of 2019, there were 79.5 million people displaced world-wide comprising 26 million refugees, 45.7 million IDPs, 4.2 million asylum-seekers, and 3.6 million Venezuelans displaced abroad [6].

TABLE I: REFUGEE POPULATION BY UNHCR REGIONS, 2017

\begin{tabular}{cc}
\hline UNHCR Regions & $\begin{array}{c}\text { Refugees (including persons } \\
\text { in a refugee-like situation) }\end{array}$ \\
\hline Central Africa and Great Lakes & $1,475,700$ \\
East and Horn of Africa & $4,307,800$ \\
Southern Africa & 197,700 \\
West Africa & 286,900 \\
Total Africa (excluding North & $6,268,200$ \\
Africa) & 644,200 \\
Americas & $4,209,700$ \\
Asia and Pacific & $6,114,300$ \\
Europe & $3,480,300$ \\
thereof: Turkey & $2,704,900$ \\
Middle East and North Africa & $19,941,300$ \\
Total &
\end{tabular}

Source: UNHCR [5, p. 14]. 
The 'Education for Life' Project in Uganda and South Sudan is one of the important efforts of the international community to promote education of the children of the refugees and IDP. The Project is founded on the European Union's concept of BRiCE, that is, "Building Resilience in Crises through Education" [7]-[9]. The concept sees education as a key tool for transforming the lives of the refugees and IDPs and believes that accessible quality education can help the displaced population not only to mitigate their immediate disasters and but also be better prepared to confront future challenges. In this context, therefore, resilience is the capacity to successfully deal with both immediate and future challenges. Accordingly, the aim of BRiCE is to achieve "improved access and completion of safe quality education for learners in fragile and crisisaffected environments," ultimately reducing educational inequality and poverty and enhancing active citizenship, health, and overall life chances [8]. Therefore, the Education for Life Project in South Sudan and Uganda created what it called the Accelerated Education Project (AEP) which supported children and youth whose education was disrupted by conflicts and facilitated education of the children of the refugees and IDP in the formal primary schools. The Education for Life Project has a four-year (2018-2022) life span [10]-[12] and centres of the Project are the Palabek Refugee Settlement in northern Uganda and Greater Kapoeta, Torit, Ikwotos and Juba in South Sudan.

The Project is managed by a consortium led by Oxfam IBIS, with Education International and Columbia University as global partners. The others are the Community Development Initiative (CDI), AVSI, Uganda National Teachers Union (UNATU), Forum for African Women Educationalists' Uganda Chapter (FAWEU), and Luigi Guissani Institute of Higher Education (LGIHE). The consortium commissioned this study to ascertain evidences that may inform policies on the education of the children of the refugees and IDP in Uganda and South Sudan in particular and Africa and the world in general, especially at this era of the COVID-19 pandemic. This paper, therefore, highlights the methodology adopted in the study, findings, and discussion of the remedies.

\section{MethodOLOGY}

The study adopted three key strategies: (i) Desk review of literature on the global state of education of the refugee and IDP children; (ii) Synthesis of the reports of the Education for Life Project in Uganda and South Sudan since inception; and (iii) Focused Group Discussion [FGD] with the key officials of the Consortium managing the Education for Life Project. These sources yielded a substantial amount of information on the subject matter, which was then analysed in qualitative terms, basically.

\section{FINDINGS}

\section{A. The African Refugee and IDP Situation}

Africa has a huge share of the IDP because of the persistent political conflicts, terrorism, and natural catastrophes. UNHCR [13] revealed that the key catalysts of the refugee situation in sub-Saharan Africa are the conflicts in the Central African Republic (CAR), Nigeria, South Sudan, Burundi, and Yemen. Incidentally, the efforts to salvage the existing refugees and IDPs in the region are hindered by new conflicts. For instance, in the late 2020 a new military conflict emerged between the Tigrayan provincial and federal armed forces of Ethiopia, leading to the death of hundreds of people on both sides of the conflict [14]. According to UNHCR [15], within two days over 7,000 Ethiopian refugees arrived in Sudan. The next few days, the number jumped to 11,000 refugees [16]. The UNHCR, therefore, feared that the Ethiopian conflict will worsen the refugee situation in Africa. It further asserts that:

Inside Ethiopia, UNHCR is deeply concerned for the more than 96,000 Eritreans living in the four refugee camps and the host community living alongside them, as well as the 100,000 people in Tigray who were already internally displaced at the start of the conflict... Roads are blocked and electricity, phone and Internet are down, making communication nearly impossible. There is a shortage of fuel, and banking services have halted resulting in a lack of cash [15].

The UNHCR [13] states that it is catering for over 18 million people in sub-Saharan Africa. This is a serious jump from the 6,268,200 million refugees reported by the UNHCR in 2017 (see Table 1). For South Sudan specifically, UNHCR [17] reveals that the country has 4.3 million displaced people which include refugees, IDPs and asylum-seekers. It adds that an estimated 1.6 million IDPs remain in South Sudan while 2.2 million became refugees in the neighbouring countries with Uganda hosting more than 1 million of them [17]. Most of the South Sudanese refugees are women and children. Save the Children [18] thus described Uganda as "Africa's largest refugee hosting country and one of the top five refugee hosting countries in the world." It further asserted that about $61 \%$ of the refugees in Uganda are below 18 years of age.

Arnauld Akodjenou, UNHCR Regional Refugee Coordinator for the South Sudan described the South Sudanese refugee emergency thus:

2019 marks the sixth year of the conflict. With 2.2 million people living in poor conditions in exile, South Sudan's refugee crisis remains the largest in Africa... Approximately $80 \%$ of the refugee population are comprised of women and children and more than 50,000 refugee children remain unaccompanied or separated. Within South Sudan, $85 \%$ of the 1.97 million internally displaced persons (IDPs) are women and children. Organizational partners are struggling to provide quality and timely assistance to survivors of sexual and gender-based violence (SGBV), while services that could offer resilience are largely out of reach, due to lack of infrastructure and resources in refugee hosting areas [19, p. 5].

\section{B. The General State of Refugee and IDP Education}

The UNHCR [20] affirms that more than half of the global refugee population $-52 \%$ - were under the age of 18 . More recently, of the 79.5 million people displaced world-wide, 30 34 million (40\%) of the are under 18 years of age [6, p. 2]. Therefore, at the global and African levels, education of the children and youth of the refugee is in crisis: they are five times more likely to miss schooling than those in normal situation; and in 2018, only 3.4 million of 7.1 million refugees 
within schooling age had access to education [17]. Similarly, the European Commission [21] asserted that 1.75 million refugee children and 1.95 million refugee adolescents were out of the primary and secondary schools, respectively. The implication of these figures is that globally the population of the refugees and IDPs requiring education is huge, and this is complicated by the fact that the low-income countries of the world are hosting over $90 \%$ of the world's population of the refugees and IDPs [15]. The refugee-receiving countries are overwhelmed and often fail to integrate the refugees into the national education sector plans; thus, the refugees at best have their own education response plan.

Some of the general obstacles to education of the children of the refugees and IDP are:

1) Learning under poor conditions: Millions of the children and youth of the refugees spend years in exile, at times stretching across decades and growing into adulthood in foreign land. UNHCR [20, p. 11] put the fact this way: "Time in exile can last for years, if not decades, and some children have only known life as a refugee." Education can therefore not wait but needs to be addressed once children and youth are displaced. The children and youth often learn in various makeshift, including open-air, classrooms where they are exposed to the elements of the weather and several security challenges, in addition to the generally poor education those in school received.

2) Huge number of out-of-school children and poor learning outcomes: The World Bank [22] reports that before the pandemic, "258 million children and youth of primaryand secondary-school age were out of school. And low schooling quality meant many who were in school learned too little ... Even worse, the crisis was not equally distributed: the most disadvantaged children and youth had the worst access to schooling, highest dropout rates, and the largest learning deficits" (p. 5). Equally, UNHCR [23] describes education of the children of the refugee as worst hit, stating that the educational provisions were outstripped by the growth of the refugee population. It asserts that four million refugee children did not attend school, and out-of-school children among the refugees increase by as much as half a million per year [23]. It also states that while globally enrolment in tertiary education for the normal population is $35 \%$, only one percent of the refugee youth enroll in tertiary education.

3) Wide gap in the education of refugee and children in normal situations: UNHCR [20] describes the refugee children and youth, compared to their peers in normal situations, as having relatively little opportunity for quality education, if at all they receive education. It also opines that the wide gap in educational opportunities develop into a "chasm" as the children and youth grow into adulthood. It supported this opinion with the following facts:

In 2017, $61 \%$ of refugee children were enrolled in primary school, compared to $92 \%$ globally. At secondary level, the figure was $23 \%$, compared with a global rate of $84 \%$. This means nearly two thirds of refugee children who go to primary school do not make it to secondary school. Even though in 2017 more than 500,000 refugee children were newly enrolled in school ... the rapidly growing refugee population means that, in percentage terms, the picture has not improved [20].

4) Wide gap in the education of the boys and girls: The refugee girls compared to boys have less educational opportunities. According to UNHCR [24] in Uganda, Ethiopia and Kenya which host most of the refugees in subSaharan Africa: In primary education, the ratio of refugee girls to boys in school is 9:10 (Uganda) and 7:10 (Kenya and Ethiopia); and in secondary education, the ratio is $5: 10$ (Uganda) and 4:10 (Kenya and Ethiopia). Yet the refugee girls constitute half of the refugee population of school going age. The situation is different for the host population in these countries where the ratio of girls to boys is 10:10 in primary education and 9:10 in secondary education [24], showing how hugely disadvantaged the refugee girls are in terms of access to education.

5) Cost of education as a major challenge: UNHCR asserts that cost is a major roadblock to the education of refugee boys and girls: "school fees, the price of uniforms, books and other learning materials and transportation are barriers to education for boys and girls alike. Even small costs can seem problematic for people who have suddenly had to abandon their livelihoods and are often denied the right to work" [24]. In addition to these costs, the girl child further faces social and cultural gender expectations and barriers.

6) Dearth of qualified teachers: In sub-Saharan Africa there is a serious shortage of qualified teachers and associated problems such as lack of teacher professional standards and inadequate continuous professional development which negatively affect learning outcomes [25]. Therefore, the refuge and IDP education in Uganda and South Sudan experience these general challenges.

7) Language of instruction: The children of the refugees and IDP face communication problems as they often settle in places that speak local languages other than theirs. Many of them are also not versed in English language which may be in more general use. For instance, during the COVID-19 lockdown, many of them could not utilise the home learning materials because they were prepared in English language.

\section{The Impact of the COVID-19 Pandemic at the Global Level}

Given that the refugee and IDP situation constitutes a state of emergency, then the addition of the COVID-19 pandemic brought about a state of extreme emergency. With the emergence of the COVID-19 virus considered to be highly contagious and deadly, lives are threatened and human activities across the world are seriously halted or limited. The situation is worse for the refugee and IDP settlements because typically they have high population density, makeshift infrastructure, and fledging social support. Thus, an extremely fragile environment is created, and both the dislodged and host communities witness an unprecedented disruption of their lives and education system. Thus, the United Nations stated that the COVID-19 pandemic created "the largest disruption of education systems in history, affecting nearly 1.6 billion learners in more than 190 countries and all continents. It opined that closures of schools and other learning spaces have impacted $94 \%$ of the world's student population, up to $99 \%$ in low and lower-middle income countries," and that the pandemic worsened the preexisting education disparities which implied a reduction of 
the educational opportunities of the "most vulnerable children, youth, and adults - those living in poor or rural areas, girls, refugees, persons with disabilities and forcibly displaced persons" [1, p. 2]. Therefore, the children of the refugees and IDP are among the worst victims of the COVID19 pandemic and the facts provided by the United Nations are corroborated by Education International [26], [27] and UNESCO Institute for Statistics [28]. For instance, the Institute reveals that 63 million teachers worldwide were affected by the school closures due to the pandemic.

\section{Impact of the COVID-19 Pandemic at the African Level}

On sub-Saharan Africa, the UNESCO Institute for Statistics [28] asserted that only $64 \%$ of the primary and $50 \%$ of secondary school teachers had received minimum training as professional teachers and the training had not included significant amount of information and communication technology which is important for online and distance education which became expedient under the COVID-19 pandemic. The teacher-student ratio is also high in the region $-1: 60$ as against 1:56 in the other low-income regions of the world. The Institute further stated that "almost half of all students affected worldwide face barriers to online learning during school closures". In other respects, the sub-Saharan region compared with others have more obstacles as outlined in Table II.

TABLE II: COMPARISON OF SUB-SAHARAN AFRICA WITH THE REST OF THE WORLD

\begin{tabular}{|c|c|c|}
\hline Indices & Worldwide & $\begin{array}{c}\text { Sub-Saharan } \\
\text { Africa } \\
\end{array}$ \\
\hline $\begin{array}{l}\text { Learners without household } \\
\text { computer }\end{array}$ & $\begin{array}{c}50 \% \text { of } 826 \\
\text { million learners }\end{array}$ & $\begin{array}{c}89 \% \text { of } 216 \\
\text { million learners }\end{array}$ \\
\hline $\begin{array}{c}\text { Learners without household } \\
\text { internet }\end{array}$ & $\begin{array}{c}43 \% \text { of } 706 \\
\text { million learners }\end{array}$ & $\begin{array}{l}82 \% \text { of } 199 \\
\text { million learners }\end{array}$ \\
\hline $\begin{array}{l}\text { Learners who cannot use } \\
\text { mobile phones to access } \\
\text { information, because they } \\
\text { are not covered by mobile } \\
\text { networks }\end{array}$ & 56 million & 26 million \\
\hline
\end{tabular}

\section{E. Interventions by the Education for Life Project in Uganda and South Sudan}

The pandemic led to the closure of all schools in Uganda and South Sudan. During the lockdown, the governments of Uganda and South Sudan delivered lessons through the radio and television which most of the children did not have access to. There was also no form of online teaching and learning. What worked (with limited success) was the distribution of home learning materials to the learners. In total, the children lost the periods of the lockdown following the pandemic, and as schools reopen, they still run the serious risk of educational marginalization due to crowded classrooms making teachers and learners vulnerable to COVID-19 virus infection. In Uganda and South Sudan there was no clear referral system and services to give Psycho-Social Support (PSS) to the learners. For South Sudan, during the COVID-19 lockdown there was no blueprint or clear plan and system for the production and distribution of learning materials or for the continuation of education of the learners in anyway. In Uganda where the plan and structures existed, they either did not work effectively or were overwhelmed.
The Education for Life Project in Uganda and South Sudan intervened in several ways to boost the education of the refugee and IDP children. The building of resilient learners, teachers and education system remained the cardinal strategy of the governments of Uganda and South Sudan and the BRICE/Education for Life Project. Building resilience is a popular strategy advocated by the United Nations [1] and the European Commission [21] and entails strengthening institutions and individuals to adapt to socio-political, economic, and environmental shocks and disruptions. The Project also addresses the vulnerability of women and girl child in the fragile environment by supporting them to meet their safety, health, and education needs. Within the resilient framework, therefore, the learners, teachers and education system are primary concerns, and the following actions were taken by the Education for Life Project:

\section{1) The Learners}

The project targeted two key sets of learner-related factors. These are (1) enrolment, completion (retention and attrition issues), transition from primary to secondary education, and assessment of the learners; and (2) safety and quality teaching and learning, including the integration of life skills and safety, literacy skills acquisition, and safe quality learning experiences. Significant impacts were recorded in all these aspects. For instance, there was increase in enrolment in the Education for Life Primary Schools between 2016 and 2018. This increase was partly due to the continuing influx of the refugees and IDPs and partly to the interventions of the Project [8]. For Uganda, enrolment increased from 1,488 in 2016 to 24,844 in 2018, while for South Sudan, it increased from 1,828 in 2016 to 2,527 in 2018. Among the important innovations introduced by the project was an alternative education and learning programme - which did not exist earlier - to address the problem of children whose education was disrupted by conflict or those with special learning needs.

As explained earlier, there was no online teaching and learning during the COVID-19 lockdown. Efforts concentrated primarily on radio and television broadcasts and the distribution of home learning materials (workbooks) to the children. The strength of the home learning materials approach depended on person-to-person contact and follow up used by the partners in both countries. However, it worked more in Uganda than South Sudan. In Uganda, the Ministry of Education and Sports developed the packages which were ten pages of work for a period of 5 months and used the government structures to distribute the home learning materials to learners. The government relied on partner contributions for automobiles, fuel, and cash contributions. Largely the government deployed the "Gobolola Internal Security" officers to support the Local Council systems to get the materials to the learners. For the refugees, AVSI (a member of the Education for Life Consortium) produced and distributed home learning materials to nearly 20,000 learners. Nevertheless, students in Primary 1 to 3 were unable to use the materials since they were in English only. Teachers taught children in the village where they reside regardless of the schools the students come from - so a teacher could teach learners from other schools and across classes. Also, every week, AVSI provided about 30 teachers (4 of whom were teachers in the mainstream primary schools) with bicycles to 
enable them to visit learners. During the lockdown, a survey in Uganda showed that only $15 \%$ of the learners had access to radio or mobile phones. The Ugandan government therefore promised to distribute radios to reach all families and televisions to all villages so that the learners could learn in clusters. But the distribution of the radio and television is yet to start. Furthermore, no learning assessment was carried out by the partners during the lockdown. However, the Ministry of Education and Sports carried out an assessment on the access to learning and learning materials but not on the learning outcomes.

In South Sudan, Oxfam arranged learners into 225 small groups which are supported by radio in accordance with the Ministry of Education's schedule of radio classes. Oxfam also distributed some radios to the learners to enable them to follow the radio lessons. In South Sudan, furthermore, the Project mobilized the Parents Teachers Associations (PTA), and community and church leaders to support learning during the COVID-19 pandemic. However, the challenge in South Sudan is absence of governmental infrastructure and education response plan to support learning during the pandemic. Besides the fact that there was no home learning material developed by South Sudan's Ministry of Education, teachers were expected to develop home learning materials. Oxfam is leading the work on the development of an assessment tool on schools' readiness for the reopening in South Sudan.

\section{2) The Teachers}

With the COVID-19 outbreak, teacher capacity on distance education was enhanced. Teachers were provided with psychosocial support and training to adapt to the new teaching methods and to be able to offer adequate support to the learners [10]-[12]. This included building the capacity of the teachers on how to provide psychosocial support particularly guidance and counselling to the learners and peers in trauma. Box I gives an outline of how the Project engaged the teachers and learners during the COVID-19 school closure.

The teacher-related activities encompassed teacher recruitment, teacher management, professional development, mentorship, and well-being [28]. Teacher capacity building focused on core competencies expected of primary school teachers in crisis situations. The competencies covered subject knowledge; teacher's role and well-being; child protection, well-being, and inclusion; pedagogy; and curriculum planning [12]. Teaching the teachers about conflict sensitive education and the need to integrate it in the teaching and learning process was important because before the project they were not exposed to such issues. Teachers were also taught the strategies for the management of large classes, the development of appropriate instructional materials, and how to resolve psychosocial problems. Furthermore, the primary school curriculum which was not revised over the years was revised to integrate the teaching and learning strategies that were conflict sensitive. Additionally, teacher motivation and satisfaction, safety and access to psychosocial support received attention.
BOX I: How THE PROJECT ENGAGED TEACHERS AND LEARNERS DURING SCHOOL ClOSURE

- $\quad$ The project partners were in regular contact with head teachers and teachers in participating project schools.

- Community learning groups established.

- Follow up on vulnerable learners to see how they were doing and if needed refer learners to appropriate safety networks and reach out to vulnerable learners to retain them in school and support their learning.

- Where not provided by the government teachers developed home learning materials for learners and corrected their homework.

- $\quad$ Engaged in teacher capacity building and where possible involved para-social workers.

- $\quad$ Provided teachers with regular messages on psychosocial issues which they could use in their communication and contact with learners and the community.

- Teachers took part in the COVID-19 health and safety trainings and acted as community focal points for COVID-19. For instance, AVSI Uganda gave orientation to 18 members of the School COVID-19 Committee on the standards of operation (SoPs) and basic requirements. The committee comprised 7 members of the School Management Committee (SMC)/PTA, and the representatives of the teachers and learners. It carried out site checks on classrooms, wash facilities, and school entry/exit. It also designated spaces to be used as isolation rooms at each AEP Centre/school.

- $\quad$ Provided some learners with personal protective materials (face masks, hand sanitisers, soaps, and water for washing of hands, etc) and health information against the COVID-19 infection.

- In further support to the COVID-19 risk reduction, AVSI worked with teachers to conduct regular home visits to the learners with their caregivers with keen focus on the teenage pregnancy.

Source: Extracts from Oxfam [12] and other sources.

For instance, according to Oxfam [12], the needs of the teachers were diagnosed including how to meet them; they were taught conflict resolution mechanism among teachers and means of coping with stress; and the teacher professional organization (trade unionism) was promoted. Other issues dealt with are the teachers' safety on the way to and from school and while at school; and improvement in their accommodation, feeding, security and teacher management. There was also psychosocial support in form of material assistance (such as provision with school meals, land, and financial support), and guidance and counselling services. They were also coached on how teachers could give one another psychosocial support through peer collaboration. Furthermore, gender equity, the management of learners with disability and student-teacher relationship received attention in the capacity building programmes for teachers [12], [26], [29]. The teacher development programmes, further, included contents on gender and conflict sensitive issues, which aimed at promoting "gender and conflict sensitive teaching and learning at school" [11, p. 48]. Mentorship which was largely lacking before the project was also part of the teacher professional development programmes.

\section{3) The Education System}

At the school level, the project targeted school management structures and mechanisms and data collection and management strategies. It also promoted education programmes for pregnant girls and young mothers, girl child education including menstrual hygiene in schools, and conflict sensitive education. School Management Committees (SMC) and Parents-Teachers Association (PTA) were considered key in the management of the school system, and these were thoroughly investigated and strengthened [11]. Special funds to assist the schools to absorb shocks and 
the collection of up-to-date quality school data were promoted. Action research about education in crisis was considered expedient and strengthened. Other critical elements in the management of the school system considered were "gender composition and issues such as disaster risk plans, education contingency budgets and plans important for effective and efficient school management" [11].

\section{LESSONS AND POLICY OPTIONS FROM THE STUDY}

\section{A. Upholding the Agreed United Nations and Continental} Frameworks

\section{1) The United Nations Resilience Framework}

The discussion focuses on the overarching need rely on the United Nations (2020) resilience framework in tackling the challenges of the education of the children of refugee and IDPs. In this regard, the United Nations called for the building of "resilient education systems for equitable and sustainable development" [1, p. 3]. It described resilience in this context as the empowering of the education systems to successfully deal with the immediate challenges of safe reopening of schools as well as positioning them to better cope with future crises. This approach entails (1) Focusing on equity and inclusion; (2) Reinforcing capacities for risk management at all levels of the education system; (3) Ensuring strong leadership and coordination; and (4) Enhancing consultation and communication mechanisms [1, pp. 4, 21-22]. The Education for Life Project in Uganda and South Sudan relied mainly on this framework and targeted three pillars of education: the learner, teacher, and education management system.

\section{2) Education as a Fundamental Human Right}

There are numerous United Nations agreed frameworks that pertain to education as a fundamental human right [3032] and African Union [33] Charter on Human and Peoples' Rights (Article 17). It is therefore an obligation on all state and non-state actors to render maximum assistance to any human being, child or adult facing the risk of losing this right. Education is crucial because it is the most effective way to empower individuals to attain their highest potentials in life and to contribute their best to societal development. As stated by the African sage, Nelson Mandela, and reiterated by Arne Duncan, United States Secretary of Education [34], "Education is the most powerful weapon which you can use to change the world." The 1951 Convention [35] and the 1967 Refugee Protocol [36], further, call for non-discrimination against refugees in the exercise of human rights while the United Nations (1990) Convention [37] (articles 12.4, 30, 43.1 and 45.1 ) seeks the protection of the education rights of migrants and members of their families.

With respect to education, the 1951 Convention states that:

1) The Contracting States shall accord to refugees the same treatment as is accorded to nationals with respect to elementary education.

2) The Contracting States shall accord to refugees' treatment as favourable as possible, and, in any event, not less favourable than that accorded to aliens generally in the same circumstances, with respect to education other than elementary education and, in particular, as regards access to studies, the recognition of foreign school certificates, diplomas and degrees, the remission of fees and charges and the award of scholarships. [35, Article 22]

Other important frameworks are the New York Declaration for Refugees and Migrants [38], and Global Compact on Refugees [39] which provide yardsticks for maximum political support to the education and general wellbeing of the refugees. The Declaration called for the protection of the human rights of all refugees and migrants, provision of education for all refugee and migrant children "within a few months of arrival", preventing and responding to sexual and gender-based violence, condemnation against xenophobic attacks on refugees and migrants, and implementing a comprehensive refugee response, among others [40]. The Global Compact on Refugees sets out the basis for "predictable and equitable" sharing of responsibilities among all state and non-state actors involved in the protection and support to the refugees and migrants. The core objectives of the Compact are to "(1) ease pressures on host countries; (2) enhance refugee self-reliance; (3) expand access to third country solutions; and (4) support conditions in countries of origin for return in safety and dignity" [39, p. 4]. On education specifically, the Compact stated as follows:

In line with national education laws, policies and planning, and in support of host countries, States and relevant stakeholders will contribute resources and expertise to expand and enhance the quality and inclusiveness of national education systems to facilitate access by refugee and host community children (both boys and girls), adolescents and youth to primary, secondary and tertiary education. More direct financial support and special efforts will be mobilized to minimize the time refugee boys and girls spend out of education, ideally a maximum of three months after arrival. $[39$, p. 26]

\section{3) Integration of Refugees in the National Education} System

Considering the relevant global and continental conventions and compacts on the right of individuals to education, the education of the refugees and IDPs cannot be left to chance or treated as a stand-alone, ad-hoc structure. It is crucial to integrate it in the national education systems of the host countries. As advocated by UNHCR [20], it should be one education system with the same standards, regulation, monitoring and updating (p. 7). It gave the example of Bangladesh where the education of the Rohingya girls and boys did not follow any formal curriculum, and the teachers were often untrained, stating that this limited the potentials of the students. Thus, it argues that:

decades of experience have taught UNHCR that the most effective way to ensure that refugee children go to school and stay there is to include them in the local school system. This requires national and local support and collaboration. When a refugee child enters a local school, it is often a first step in the community to welcoming them into their midst...contrary to popular misconceptions of who refugees are and where they live, only $30 \%$ of them reside in camps; the majority are to be found in villages, towns, and cities, in private homes or in unofficial settlements. [20, p. 34].

UNHCR [20], [23] further stated the need for the refugee and IDP children not only to enroll in the national education systems but also follow proper curriculum throughout out 
their studies from primary and secondary education so they can obtain recognized qualifications. This will enable them to pursue university or vocational education in the host countries or when they return home. As asserted by UNHCR [20], "We cannot build a future by shunting refugee children into a parallel system of schooling that relies on outdated materials, makeshift classrooms or untrained teachers. We cannot improvise an education and imagine that this is good enough" (p. 8).

\section{4) Funding of Education}

Fund is an important enabler of educational interventions. The need for the refugee and IDP education often overwhelms the host countries. It is even more serious as $92 \%$ of the world's school-age refugees are in the low-income countries [23]. Therefore, for those refugees in the lowincome countries, their situation is desperate, "with resources stretched and a chronic shortage of schools and teachers" [24]. Thus, as advocated by UNHCR there is need for strong local and international partnerships to provide resources and expertise to reach millions of school age refugee children who are out of school and those in school but having less than the desired quality of education. Furthermore, among the policy recommendations of the United Nations [1] is the need to protect education financing and coordinate for impact. It stated that with the COVID-19 pandemic-induced global economic recession, which is one of the worst in memory, national and international authorities must protect education financing by several measures that include: strengthening domestic revenue mobilization, preserving education finance against inefficiencies in education spending; collective resolution of the debt crisis by the international community, and protecting "official development assistance (ODA) for education" [1, p. 3].

At the African level, the Ministers of Education at a panAfrica high-level conference on education came up with a decision (Called the Nairobi Declaration, 2018) stressing earlier commitment of the member states to allocate $4-6 \%$ of the national Gross Domestic Product (GDP) or $15-20 \%$ of total national expenditure to education [41]. In addition, it called for strategic financial management that includes equitable allocation of education resources to cater for diversity, inclusion, and education in emergencies. Other strategic options advocated by the Ministers are (1) efficiency, transparency and accountability to optimize (optimising teacher allocation, budget tracking, public expenditure reviews/national education accounts); (2) Promoting innovative financing for education including consideration of the proposed Africa Education Fund; and (3) Advocacy for tax reforms to increase public revenue and the share of public resources for education and related social services [41]. UNESCO [25, p. 31] also backed these Ministerial decisions (called the Addis Ababa Action Agenda) when it was first conceived by the African Union. UNESCO stated that though the national contexts are diverse, the spending targets for education set by the Addis Ababa Action Agenda are "crucial reference points".

\section{B. Learners: Accessible, Relevant and Equitable Education}

1) Gender and Equity Issues

The deprivations of the girl child and women remain burning issues across the world. It is even more serious among the refugee and IDP school age children. The Education for Life Project in Uganda and Sudan [7], [24] and other sources identified serious gender issues that must be addressed. These include issues related to the opportunity cost of going to school. For instance, for the girl child to attend school, the family forfeits incomes from hawking items and dispenses with her household chores and services such as taking care of siblings or older members of the family. This calls for action to provide financial support and enhance the economic viability to the families so that cost will not be a reason for families to inhibit the education of the girl child. The direct cost elements associated with school uniforms, books and sometimes transportation to school are also to be addressed. The transportation problem makes it imperative to have schools within a limited distance to all pupils. UNHCR [24] reports that "a major obstacle to both refugee boys and girls attending school is cost. According to UNHCR field staff, school fees, the price of uniforms, books and other learning materials and transportation are barriers to education for boys and girls alike. Even small costs can seem problematic for people who have suddenly had to abandon their livelihoods and are often denied the right to work."

The provision of toilets and hygiene, lessons, and materials for the girl child as well a guarantee of their safety from rape and violence are all issues that are still needing more action. Furthermore, the Education for Life project discovered that fewer females than males enter secondary education. This calls for measures that to address issues of transition to secondary education by the girl child. Generally, a balance in the number of male and female teachers will be necessary so that the girl child could have female teachers as models and to give the school climate a gender-balanced atmosphere. Gender issues should be mainstreamed in the curriculum also and not just taught as stand-alone subjects. This implies that all ramifications of the teaching and learning processes including subjects, instructional materials, delivery strategies, learning assessment, and student-teacher relations should be integrally gender-balanced. The drive towards gender balance in education is strongly supported by the United Nations [42] Convention which requires that all discriminations against women be eliminated; UNESCO [43] which demands inclusion in education; and the United Nations [44] Sustainable Development Goal (SDG) 4 which is about quality education and inclusivity. Attention should also be given to the strategies for gender inclusion and women empowerment enunciated by UNESCO [45] which have two strategic objectives namely, (1) Strengthen education systems to be gender transformative and promote gender equality, and (2) Empower girls and women through education for a better life and future, and three thematic priorities, namely, (1) Empower girls and women through education for a better life and future, (2) Better legal, policy and planning frameworks to advance rights, and (3) Better teaching and learning practices to empower (p. 5). Also, furthermore, cognizance should be taken of the principles of equity and inclusion put forward by UNESCO [43] which include (1) valuing the participation and achievement of all learners regardless of background, (2) Recognizing and beneficially managing diversity; (3) Quality data collection on the learners' access, participation and achievement to 
inform policy decisions; (4) Building a common understanding of inclusive education and encouraging supportive learning environments; (5) Engaging key stakeholders in education and community regarding equity and inclusion; and (6) Effective implementation and monitoring of policies and projects on equity and inclusion.

\section{2) Food security and nutrition}

Food and nutrition have been acknowledged globally to be strategic issues especially for the vulnerable population who suffer hunger and starvation. For this reason, both the United Nations, countries and international organisations have devoted resources to school feeding programmes and other ways of meeting the food and nutritional needs of the vulnerable populations. In the Education for Life project in Uganda and South Sudan, as well as the research by Education International Africa Region [46], hunger was revealed to be plaguing many of the vulnerable students and truncating their dreams for a better education. There were reports that for some children, the school meals were the only means they could have for many days. Therefore, the importance of the school feeding programme cannot be overemphasized. It is in this line that the United Nations [39, p. 31] called for contribution of resources and expertise to "facilitate access by refugees and host communities to sufficient, safe and nutritious food, and promote increased self-reliance in food security and nutrition, including by women, children, youth, persons with disabilities and older persons".

\section{3) Psychosocial support for Learners}

The refugee and IDP school age children are victims of the worst violent experiences imaginable. Their innocence is violated at tender ages, and they live with trauma for a long time. In addition to this, they regularly face threat to their lives due to insecurity while struggling with entirely new forms of lives in strange environments. Unless they receive adequate psychosocial support, effective learning cannot take place while their minds are troubled and fearing for their lives and for the unknown. Support can be given in form of guidance and counselling, addressing specific psychosocial complaints or symptoms manifested by the learners, ensuring the health and safety, and mainstreaming psychosocial supporting subject matters in the school curriculum.

\section{4) Curricular and Co-Curricular Activities}

The Education for Life Project found insufficient cocurricular activities for students and underscored the need for these. That is, the school curriculum needs to be adequately complemented by co-curricular (extra-curricular) activities to ensure that the students' learning experiences are fully enriched. This is important because the out-of-class activities and programmes occurring within the contexts of clubs and societies and other school-regulated programmes enable the students to meaningfully interact with peers, the school and community and enhance their interpersonal skills, self-worth, and dignity. They further help the students to discover their hidden talents in various areas of life - sports, leadership, friendship, arts, science, and agriculture, among others. As asserted by UNHCR [24], "extracurricular activities provide remedial, enrichment or mentoring services to enable girls to catch up (where necessary), boost their studies and thrive both academically and emotionally. While these should not be seen as an alternative to regular school, they can help to improve academic performance and, as a result, selfconfidence."

\section{5) Online infrastructure and capacity}

Online education has been important for a long time now. UNESCO Institute for Information Technologies in Education [47] quotes Irina, Director General of UNESCO as stating that "new technologies are the way to connect the dots across the new agenda [SDG 4] - to connect education quality, equality and inclusion, reaching the unreached, and learning throughout life." However, the emergence of the COVID-19 pandemic has raised the status of online education to an emergency. The Education for Life project in Uganda and Sudan demonstrated that the education of the students was completely grounded with when the pandemic occurred. The governments of both countries (Uganda and South Sudan) came up with plans for some form of distance education, particularly the use of radio and television but this did not work or help in any significant way. For instance, the Ugandan government promised to send television to all villages and radio to all families so that students could learn in clusters through these devices. However, these are yet to be actualized. What worked extremely well especially for Uganda, and far less for South Sudan, was the development of learning materials and delivering them to the homes of the learners as take-home packages. Teachers living within the localities or villages then tried to reach and assist students with their homework whether the students came from the teacher's school or not. It means that teachers assisted learners across different ages, classes, and schools.

The COVID-19 era therefore calls for mixed strategies that involve take home packages, radio, television, handsets, and other digital devices as well as exploring the extent to which online platforms could help to ensure the continuity of learning during and after the pandemic. The United Nations [1] calls for the expansion of the definition of the right to education to include connectivity and the removal of barriers to connectivity, and the strengthening of data and monitoring of learning. UNHCR [20] believes that digital access and connectivity will greatly assist the refugee children to overcome their "feelings of isolation, find peer support and stay connected to family" and also to "access learning opportunities from other ends of the globe" (p. 44). Indeed, it reported the cases of connected learning where online courses, lectures, and curated content for the primary to the university levels were tailored to the needs of the refugee learners and proved very successful. According to the UNHCR, connected learning courses gather students in a centre to learn together using online content and tutoring support to complement face-to-face teaching in a way that keeps distance learners engaged. Lectures can be delivered remotely but are also given by visiting academics and staff who work on location. Without a common campus, students can nonetheless create their own communities, both on site and with their peers on other campuses, and thereby engage in group assignments as well as conventional individual tasks [20 p. 45].

It revealed that from 2017 to the present time, over 7,000 refugee and host community children have benefitted from 
connected learning in 12 different countries - France, Germany, Afghanistan, Thailand, Malawi, Iraq and others supported by the UNHCR, various consortia, universities, international and non-governmental organisations. In a joint pilot project, UNHCR and Microsoft 4Afrika provided wi-fi connectivity to settlements, supported local content providers for 12 months, and distributed 1000 smart phones, 40 laptops and 10 tablets to help the students to learn [20, p. 49]. These initiatives highlight the fact that connected learning is possible for the children of the refugees and IDP if there is the political will.

\section{6) Learning Assessment}

Throughout the COVID-19 lockdown, and even with some form of online and distance education and take-home assignments for the students, one thing stood out clearly: there was no meaningful learning assessment. As revealed by the surveys (Education International Africa Region [46], the ministries of education and schools began to contemplate about how to assess learning only when the schools reopened. At that time, many schools had to rely on the continuous assessments or mass promotion rather than the standard examinations. Therefore, there is need to plan for effective learning assessment along with the continuation of learning either in the case of online and distance education or takepackages - so that the school calendar could run along with all the relevant elements of teaching and learning including learning assessment. This is especially important as Education International [48] asserted: "The primary purpose of learner assessment is to inform strategies to improve the teaching and learning process."

\section{Teachers: Empowerment}

\section{1) Standards Based Profession}

Professional competencies prescribed by the Professional Standards for Teachers and School Leaders should underlie teacher preparation, recruitment, retention, and continuous professional development. The consideration for quantity (number of teachers demanded) should not outweigh the consideration for quality of teachers because ultimately only quality teachers can facilitate the actualisation of quality, equity and inclusion demanded by SDG4 and CESA. As put by Education International [48], "quality education requires quality teachers." Indeed, there has been a global consensus that teacher professional standards have become overarching and that teacher competences - knowledge, skills, values, and attitudes - should be gauged against the provisions of the Professional Standards [49]-[51]. The outcome of the $10^{\text {th }}$ Policy Dialogue Forum of the International Task Force on Teachers has also developed "an international guidance framework for professional teaching standards" to assist the regions of the world to come up with their regional standards. Similarly, the African Union Commission developed and approved a continental framework of teacher professional standards and charged member states to develop and align their teacher professional standards to the continental model. These moves end a situation where teaching is treated as a profession without standards. Therefore, all education actors should accord maximum consideration to the national, continental, and global framework of teacher professional standards in the management of the teaching force.

\section{2) Online Infrastructure and Capacity for Teachers}

The shift from the traditional mode to online and distance education, which attained its peak at the outbreak of the COVID-19 pandemic revealed the huge gap in infrastructure and capacity of teachers to meet the demands of online and distance education. Priority should, therefore, be accorded to the connectivity of schools, and support given to teachers by supplying them with laptops and or tablets and providing them with adequate professional development to keep abreast of the developments and state of the art in digital education. The study by Education International Africa Region [46] revealed some cases where the communication companies granted teachers and learners free access to educational portals without paying for data or bandwidth. This was achieved through the joint efforts of the teachers' unions, ministries of education and public. The case of connected learning cited above in the case of the learners are also useful here and implies that the teachers should be placed at the centre of the connected learning initiatives and empowered as facilitators of learning. The need to give paramount attention to the digital connectivity of schools is further stressed by the African Union's [52] "DOTSS" framework which serves as an important guide on the move to enhance online and distance education.

\section{3) Indispensability of the Teacher in the Digital Era}

The study by Educational International Africa Region [46] revealed that majority of the teachers fear that the application of technology in education may lead to the loss of their job this view was held by $60 \%$ of the respondents in that survey. Education International [53] had equally addressed this fear, stating that while technologies are desirable in education, they should never be used to supplant or replace teachers; rather they should be employed to supplement teaching. Thus, Education International referred to its International Protocol on the use of Information and Communications Technology in Education and asserted that "new technology can never substitute for the relationship between teacher and student or teacher and class." To allay the teachers' fear, therefore, it recommended that unions, on behalf of the teachers and education support staff, should participate in government decisions concerning the integration of technology in education.

\section{4) Emerging Issues}

The content of education in emergencies has ever been expanding. All the while it has been about the effects of conflict, violence, armed struggles, and natural disasters and how to manage them. Now, it must include the impact of COVID-19 pandemic on education and how to ensure safety of human lives and the continuity of quality teaching and learning. In addition to these are many other issues that include endemic gender disparities and challenges of teaching large classes. These require the periodic revision (updating) of teacher professional development content and materials as well as capacity building to enable the teachers understand, adjust and better manage the challenges. As indicated earlier, the emerging issues also need to be mainstreamed in the school curriculum to make both teachers and learners aware and help them to develop resilience towards the emerging contexts. This why Oxfam [7] advocates the introduction of Conflict Sensitive Education (CSE) to help the teachers and 
learners within the environment of conflict to cope. Oxfam equally emphasized the need for mentorship for the teachers on these issues.

\section{5) Psychosocial Support to Teachers}

Teacher motivation is the foundation of excellent teaching [54] because teachers struggling with lack and want cannot have the best social and psychological disposition to put up their best performance. For this reason, the necessities of the teachers, ranging from regular and sufficient pay, habitable accommodation, security and food and nutrition, have to be addressed. Teachers also need guidance and counselling by professionals to deal with their socio-psychological experiences in the context of conflict [29], [55]. The Education for Life project in Uganda and South Sudan made good use of text messaging to reach teachers during the COVID-19 lockdown and the teachers in turn reached out to students. This is one of the psychological tools that could be explored and strengthened. In the Education International Africa Region [46] study, 62\% of the respondents stated that the government did not provide any support to the teachers during the COVID-19 lockdown. This trend must be revised, and the government should be more responsive towards the needs of teachers at this trying time.

\section{6) Social Dialogue Between Unions and Government}

Social dialogue between the government and teacher unions are considered critical for dealing with sensitive and crucial issues affecting teaching and learning [53], [54]. The Education International Africa Region [46] study revealed that only $9 \%$ of the respondents opined that they were consulted by government and their views considered. The rest either stated that they were consulted but their views only occasionally taken $(51 \%)$, consulted but views ignored (11\%) or they were not consulted at all $(28 \%)$. There is need, therefore, to radically improve the relations and joint decision-making between the government and the unions because it is a fundamental right of the teachers and education support personnel through their unions to have a say in the making of their conditions of work and in creating the future of their profession.

\section{7) Promotion of Teacher Professional Associations and Unions}

The teachers' union is a veritable instrument for the coherence of the body of teachers. It empowers their voices so they could be heard in decision making and effectively take in part in public debates about issues that affect education. For these and other reasons, promoting teacher unionism helps to build the resilience of the teaching force. The government and other key stakeholders should therefore take interest in supporting teacher unionism. Teachers should be enlightened about the professional gains of teacher unionism and encouraged to participate actively.

\section{Education System: Strengthening the Structures and Mechanisms}

\section{1) School Leadership (Standards Based/Competency Driven)}

School leadership has not received the attention it deserves given the fact that the success or failure of teaching and learning and other school programmes hinge largely on the quality of school leadership. Some authorities, for instance,
Leithwood et al [56] have found that $27 \%$ or more of the variation in learner outcomes could be attributed to school leadership and that "there is no recorded case of school improvement without talented leadership." Due to paucity of qualified teachers and school leaders or simply due to the absence of professional standards for school leadership, individuals are appointed as head teachers and principals without the requisite rigorous screening and qualifications. In the same way that there is global consensus that teacher professional standards are necessary, there is equally a consensus that the appointment of school leadership should henceforth be based on the leadership standards. This means that the school leaders should be appointed from the pool of highly qualified teachers who have attained advanced level in the teacher career path [49], [50], [57]. The African Union framework of teacher professional standards includes the school leadership standards. African Union member states are, therefore, expected to develop and align their own leadership standards to the continental model and ensure their enforcement.

2) School Management Committee and Parents-Teachers Association

The School Management Committee (SMC) and ParentsTeachers Association (PTA) are two important instruments for stabilizing and enriching the management of schools. These should be strengthened through encouraging their establishment where they do not exist and supporting active membership, periodic meetings, quality agenda and decisions, and implementation, monitoring and evaluation of decisions. Oxfam [7, p. 53] further strongly recommended capacity building programmes for members of the SMC and PTA to optimize their contributions to the management of the school. The capacity building for members of the SMC and PTA should cover decision-making processes, monitoring and evaluation, data collection, and the importance and application of educational technologies, among others.

3) Community Participation in the Implementation of Sensitive Programmes

In cases of emergencies and pandemics such as COVID19 , and for the implementation of sensitive programmes, the school management should work in collaboration with the different stakeholders (such as traditional and religious rulers, political representatives, and illustrious personalities). This will ensure that the community takes ownership of such sensitive programmes and promotes its sustainability.

\section{4) Coordination of the Education System}

The education system has many actors and sub-systems. This requires effective coordination which will depend on the quality of the leadership of the ministry of education, education districts and local education authorities and school inspectors. It is important, therefore, that the leadership of these levels be placed on professional teachers and leaders with proven integrity and competences. In other words, the professional standards should be emphasized at all levels of the education system to underscore the professionalization of teaching. In plain terms, those who must teach, lead a school or administer education must themselves be teachers who are professionally trained, registered and licensed by the teaching regulatory authorities. These are the minimum conditions in 
the other professions - medical, legal, engineering and others - and the renaissance in the teaching profession calls for the adoption of these time-tested minimum professional terms and conditions. Effective coordination will also require well laid out operational procedures and communication channels and mechanisms that leverage on information and communication technology and other modern best practices in educational planning and administration.

\section{5) Education Policies}

The education policies are the web that hold the system together. They dictate the structures, tools, instruments, processes, operations, impacts, outcomes and even point to the nature of expected impacts of teaching and learning and other educational programmes. Therefore, there is need for stakeholders to constantly review education policies with a view to closing identified gaps. The review should be informed by research and monitoring and evaluation which are key elements that bring up evidence-bases for appropriate actions.

\section{6) Expansion of Schooling Opportunities}

Of particular interest (in the case of the refugee and IDP children) is the need to expand schooling opportunities to accommodate the influx of the children of refugees and IDP in the camps and rural and urban areas of the affected countries. As asserted by UNHCR [20, p. 35], "supporting educational facilities in those environments [refugee camps] not only benefits a large number of refugees, but it also serves local populations in countries where the educational infrastructure is already overstretched - making long-lasting differences for host communities and boosting relations with refugees." Education International [48] further advocated a broad approach to education which goes beyond the quest for literacy and numeracy and emphasize "creativity, curiosity, civic-mindedness, solidarity, self-discipline, self-confidence, compassion, empathy, courage, self-awareness, resilience, leadership, humility, peace and more."

\section{7) Accelerated Education Programmes (AEP)}

The Education for Life project in Uganda and particularly South Sudan demonstrated that teaching and learning could be specially designed to cater for the refugee and IDP children who had lost schooling years as out-of-school children or who due to trauma and other debilitating conditions of the violent environment could not cope with the normal schools. The AEP is one of the best practices that can be replicated in other areas where children must have lost school years and unable to attend the regular schools and classes. Nevertheless, the curriculum of such programmes as stated earlier should be comply with the national educational standards and lead to approved qualifications.

\section{8) Alternative Education Options - Pregnant girls etc.}

The refugee and IDP girl child also witness various forms of violations and crime, particularly rape, forced marriages, and unexpected pregnancies. There is need, therefore, to fashion out programmes that can accommodate such child victims to enable them to complete their education.

\section{9) Quality School Data}

Quality data is at the heart of educational planning and administration. UNESCO Institute for Statistics [58] describes data as a public good that has the power to transform lives. Therefore, there is need to strengthen the capacity of schools and the education system to collect, analysze and utilize quality educational data for planning and decision making. Such data relating to student enrolment, attrition, performance, transition to higher classes, student's background and participation in extra-curricular activities, teacher recruitment, teacher qualifications and performance, teachers' psychosocial needs, teacher unionism, activities of the SMC and PTA and many other issues require quality and systematized data analyzed in line with the best practices. The data should also be made interoperable not only with the national education data database but also the continental and global data templates as much as possible. Data for the management of the education system can also reflect the following themes set out by the UNESCO Institute for Statistics [58]: international monitoring, tracking the gender gap, out-of-school children, international comparative data, and learning assessment. Others are education finance; supply and demand for teachers; science, technology, and innovation; culture and development; information and communication technology; and capacity building for data management specialists.

\section{0) COVID-19 Protocols}

The COVID-19 pandemic calls for cautious approach to the reopening of schools. The United Nations [1, p. 3] calls for the suppression of the transmission of the virus as a first step towards ensuring the safe reopening of schools. This will require giving due attention to the Protocols established by the World Health Organisation (WHO) regarding the pandemic, and it includes the use of mask, social distancing, provision of water for sanitation and regular washing of hands, use of sanitizers and immediate isolation and treatment of infected individuals in the appropriate COVID-19 treatment centres. The International Task Force on Teachers and International Labour Organisation [59], Education International [60] other authorities have issued important guidelines on how to safely reopen and maintain the schools and these should be strictly adhered to by all schools and educational institutions.

\section{CONCLUSION}

The findings of the research show that the children of the refugees and IDPs study in the most deplorable situations and have limited access to quality and equitable education. This reality threatens the United Nation's Sustainable Development Goal 4 which envisages "inclusive and equitable quality education" and "lifelong learning opportunities for all" by 2030. Therefore, there is need for urgent actions by the global stakeholders, both state and nonstate actors alike. In doing so, the United Nation's Resilience Framework provides the overarching approach and ensures that the three critical pillars of education - the learner, teacher, and education system - receive maximum attention. This will empower education to overcome not only the immediate but also future threats to sustainability. 


\section{ACKNOWLEDGMENT}

Professor Steve Nwokeocha thanks the consortium that commissioned this study. It comprises the following organisations: Education International, Oxfam Novib, Oxfam

IBIS, Oxfam South Sudan, Oxfam in Uganda, AVSI (both in Uganda and South Sudan), Community Development Initiatives, Columbia Global Centers, Uganda National Teachers' Union, Forum for African Women Educationists Uganda, and the Luigi Giussani Institute of Higher Education.

\section{FUNDING}

This research was financed by a consortium comprising Education International, Oxfam, Columbia Global Centers, Forum for African Women Educationists, and several others.

\section{REFERENCES}

[1] United Nations, Policy brief: Education during COVID-19 and beyond, New York: UN, 2020, August.

[2] UNHCR. (2021). What is a refugee? https://www.unher.org/what-is-a refugee.html\#: :text=Refugees $\% 20$ are $\% 20$ people $\% 20$ who\% 20 have,p ossessions\%2C\%20jobs\%20and\%20loved\%20ones.

[3] UNHCR. (2021). Internally Displaced People. https://www.unhcr.org/internally-displaced-people.html

[4] UNHCR. (2020). Massive floods in Sudan impact thousands of refugees and IDPs.

https://www.unhcr.org/afr/news/videos/2020/9/5f6c84a94/massivefloods-in-sudan-impact-thousands-of-refugees-and-idps.html.

[5] UNHCR, Global trends: Forced displacement in 2017, Geneva: UNHCR, 2018. https://www.unhcr.org/5b27be547.pdf.

[6] UNHCR, Global trends: Forced displacement in 2019, Copenhagen: UNHCR, 2020. https://www.unhcr.org/globaltrends2019/.

[7] Oxfam, Baseline survey report for BRICE EU-Oxfam Project in Northern Uganda and South Sudan, Juba: Oxfam, 2019. Prepared and submitted by Pascal Pax Andebo (PhD), Rev. Dr. Epiphany Odubuker Picho $(\mathrm{PhD})$ and Sunday Olishe Etrima.

[8] Oxfam, Education for Life: Baseline survey report for resilient learners, teachers and education systems in South Sudan and Uganda, Juba: Oxfam, 2019. Report prepared by Pascal Pax Andebo (PhD), Rev. Dr. Epiphany Odubuker Picho (PhD), Salome Awidi Osire (PhD) and Sunday Olishe Etrima.

[9] Oxfam, Monitoring, evaluation accountability and learning plan: Resilient learners, teachers and education systems in Southern Sudan and Uganda project, 2018-2021, Juba: Oxfam, 2019.

[10] Oxfam, BRICE/Education for life advocacy messages [A manuscript], Juba: Oxfam, 2020.

[11] Oxfam, Resilient learners, teachers, and education systems in South Sudan and Uganda: Annual Report March 2019 - February 2020, Juba: Oxfam, 2020.

[12] Oxfam, BRICE learning week, Juba: Oxfam, 2020.

[13] UNHCER. (2020). Sub-Saharan Africa hosts more than 26 per cent of the world's refugee population.

https://www.unhcr.org/africa.html\#: :text=Sub\%2DSaharan\%20Afric a\%20hosts\%20more, $\% 2 \mathrm{C} \% 20$ Nigeria\%20and\%20South\%20Sudan.

[14] CBS News. (2020). Ethiopian leader rejects concerns of a brewing civil war as clashes reportedly leave hundreds dead. November 10. https://www.cbsnews.com/news/ethiopia-abiy-ahmed-rejects-tigraycivil-war-concerns-as-hundreds-reportedly-killed/ (Accessed November 11, 2020)

[15] UNHCR. (2020). Clashes in Ethiopia's Tigray region force thousands to flee to Sudan. https://www.unhcr.org/news/press/2020/11/5fabe9fd4/clashesethiopias-tigray-region-force-thousands-flee-sudan.html.

[16] UNHCR. (2020). Over 11,000 asylum seekers flee Ethiopia across border to Sudan.

https://www.unhcr.org/afr/news/press/2020/11/5fad7a4f4/over-11000asylum-seekers-flee-ethiopia-across-border-to-sudan.html.

[17] UNHCR. (2021). South Sudan refugee crisis. https://www.unrefugees.org/refugee-facts/.

[18] Save the Children. (2019). Accelerated education programming (AEP): Children, families, teachers and educational stakeholders' experiences of AEP in Uganda. London: Save the Children. https://resourcecentre.savethechildren.net/node/14472/pdf/aep_researc h_study_report_final.pdf.

[19] UNHCR. (2020). South Sudan regional refugee response plan, January 2019 - December 2020.Nairobi: UNHCR Regional Refugee Coordination Office. https://www.unhcr.org/5c330cf34.pdf

[20] UNHCR. (2018). Turn the tide: Refugee education in crisis. Geneva: UNHCR, https://www.unhcr.org/5b852f8e4.pdf.

[21] European Commission. (2020). Giving everyone a chance to access education. https://ec.europa.eu/internationalpartnerships/stories/giving-everyone-chance-access-education_en.

[22] World Bank Group. (2020, May). The Covid-19 pandemic: Shocks to education and policy responses. https://openknowledge.worldbank.org/bitstream/handle/10986/33696/ 148198.pdf? sequence $=4 \&$ is Allowed $=y$.

[23] UNHCR. (2020). Four million refugee children go without schooling: UNHCR report Turn the Tide: Refugee Education in Crisis study finds refugee enrolment in school is failing to keep pace with growing displacement worldwide. https://www.unhcr.org/news/latest/2018/8/5b86342b4/four-millionrefugee-children-schooling-unhcr-report.html.

[24] UNHCR. (2018). Her turn: It's time to make refugee girls' education a priority. https://www.unhcr.org/herturn/.

[25] UNESCO. (2016). Incheon Declaration and Framework for Action Towards inclusive and equitable quality education and lifelong learning for all.

http://uis.unesco.org/sites/default/files/documents/education-2030incheon-framework-for-action-2016-en_0.pdf.

[26] Education International, BRICE/Education for life progress report, Brussels, 2020.

[27] Education International, Survey report on Covid-19 and education: How education unions are responding, Brussels: EI, 2020.

[28] UNESCO Institute for Statistics, Covid-19: A global crisis for teaching and Learning, Montreal: UIS, 2020.

[29] D. Falk, D. Shephard, \& M. Mendenhall, Teacher well-being amidst displacement and fragility in Uganda and South Sudan. Paper presented at a Teachers in Crisis Contexts Roundtable held in Beirut, Lebanon, November 4-5, 2019, organized by the Inter-Agency Network for Education in Emergencies; Oxfam; UNESCO International Task Force on Teachers; \& Education International.

[30] United Nations, Universal declaration of human rights, New York: UN, 1948

[31] United Nations, International Covenant on Economic, Social and Cultural Rights, New York: UN, 1966.

[32] United Nations, Convention on the Rights of the Child, New York: UN, 1989.

[33] African Union, African charter on human and peoples' rights, Addis Ababa: AUC, 1986. https://www.achpr.org/legalinstruments/detail?id=49.

[34] United States Agency for International Development, USAID. (2013). Education: The most powerful weapon for changing the world https://blog.usaid.gov/2013/04/education-the-most-powerful weapon/\#: : :text=As\%20Nelson\%20Mandela\%20says $\% 2 \mathrm{C} \% 20 \% \mathrm{E} 2$ $\% 80 \% 9$ CEducation,illness $\% 2 \mathrm{C} \% 20$ and $\% 20$ to $\% 20$ fostering $\% 20$ peace

[35] United Nations (1951). The refugee convention. New York: UN https://www.unhcr.org/4ca34be29.pdf.

[36] United Nations, Protocol relating to the Status of refugees, New York: UN, 1967.

https://www.ohchr.org/Documents/ProfessionalInterest/protocolrefug ees.pdf.

[37] United Nations. (1990). International Convention on the Protection of the Rights of All Migrant Workers and Members of Their Families. https://www.ohchr.org/Documents/Publications/FactSheet24rev.1en.p df.

[38] United Nations, The New York declaration for refugees and migrants, New York: UN, 2016.

[39] United Nations, Global compact on refugees, New York: UN, 2018.

[40] United Nations Office of the High Commissioner on Human Rights, New York Declaration, New York: UN, 2020

[41] African Union, Nairobi declaration and call for action on education: Bridging continental and global education frameworks for the Africa we want. Outcome of the Pan African conference on education held in Nairobi Kenya, April 25-27, 2018.

[42] United Nations, Convention on the Elimination of All Forms of Discrimination against Women, New York: UN, 1981.

[43] UNESCO, A guide for ensuring inclusion and equity in education, Paris: UNESCO, 2017. https://unesdoc.unesco.org/ark:/48223/pf0000248254

[44] United Nations, Transforming our world: The 2030 agenda for sustainable development. A/RES/70/1. New York, UN, 2015. 
www.sustainabledevelopment.un.org.

[45] UNESCO, From access to empowerment UNESCO strategy for gender equality in and through education 2019-2025, Paris: UNESCO, 2019.

[46] Education International Africa Region, Covid-19 and education: How education unions in Africa are responding - Survey report, Accra: EIRAF, 2020.

[47] UNESCO Institute for Information Technologies in Education, About IITE, Moscow: IITE, n.d.

[48] Education International, Education for all and the global development agenda beyond 2015: Principles for a post-2015 education and development framework, Brussels: EI, 2015.

[49] African Union Commission, African continental framework of standards and competences for the teaching profession. Addis Ababa: AUC, 2020.

[50] International Task Force on Teachers for Education 2030, Outcome statement of the 10th Policy Dialogue held in Lome, Togo, 18-21 September, 2017.

[51] International Task on Teachers for Education 2030, Concept note: Consultation workshop - Development of an international guidance framework for professional teaching standards. Paris: ITF, 2019.

[52] African Union, Equitable, quality and relevant education in Africa: The DOTSS framework and agenda for innovation, acceleration and transformation of Africa's education systems. Addis Ababa: AUC, 2020.

[53] Education International. (2020e, July). Shaping the future of the teaching profession. https://www.ei-ie.org/en/detail/16865/shapingthe-future-of-the-teaching-profession.

[54] UNESCO IICBA, 2017.Teacher support and motivation framework for Africa: Emerging patterns. Addis Ababa: IICBA, 2017.

[55] Teacher Task Force \& ILO, Supporting teachers in back-to-school efforts Guidance for policy-makers. Paris: UNESCO, 2020. https://unesdoc.unesco.org/ark:/48223/pf0000373479?fbclid=IwAR1 AT--JAAOq51JrC9Oaf3ri3hhFhDf9yxc47pfpQfvhwMXLQjdPR1nagc.

[56] Department of Basic Education, South Africa, National framework on induction of newly appointed principals, Pretoria: DBE, 2015.

[57] Australian Institute for Teaching and School Leadership, AITSL, National professional standards for teachers. Carlton South: Education Services Australia, 2011.

[58] UNESCO Institute for Statistics, Data to transform lives. Montreal: UIS, n.d

[59] International Task Force on Teachers for Education 2030 and
International Labour Organisation, Supporting teachers in back-toschool efforts Guidance for policy-makers. Paris: UNESCO, 2020 https://unesdoc.unesco.org/ark:/48223/pf0000373479?fbclid=IwAR1 AT--JAAOq51JrC9Oaf3ri3hhFhDf9yxc47pfpQfvhwMXLQjdPR1nagc.

[60] Education International, EI Guidance to reopening schools and education institutions. Brussels: EI, 2020. https://www.eiie.org/en/detail/16760/education-international-guidance-onreopening-schools-and-education-institutions.

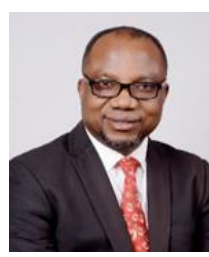

Steve Nwokeocha is a Nigerian citizen born in Owerri, Imo State of Nigeria on May 20, 1964. He obtained a Bachelor's degree in Sociology at the University of Calabar, Nigeria in 1988; and Master's and Doctorate degrees in Sociology at the Bayero University, Kano, Nigeria in 1994 and 1998, respectively. He also got a Post Graduate Diploma in Education from Ahmadu Bello University, Zaria, Nigeria in 1993 and Master of Business Administration from Bayero University, Kano, Nigeria, in 2002.

He is currently a Professor of Sociology of Education at the University of Calabar, Calabar, Nigeria and Executive Director, Africa Federation of Teaching Regulatory Authorities (AFTRA), Abuja, Nigeria. The latter is an intergovernmental umbrella of the Ministries of Education and National Agencies regulating Teaching in the 55 member States of the African Union. $\mathrm{He}$ is also, Co-Chair of the African Union's Teacher Development Cluster which oversees the development and implementation of Teacher policies in Africa. Previously, he served as the Director of Professional Operations at the Teachers Registration Council of Nigeria (TRCN), an agency of the Federal Ministry of Education responsible for the regulation of the Teaching profession in Nigeria.

Professor Nwokeocha is a renowned international scholar and authority in the Teaching profession. He represents Africa in the International Forum of Teaching Regulatory Authorities (IFTRA, www.iftra.org) which is the world governing body of the Teaching profession. He is a member and Fellow of numerous national and international organisations: He is a Fellow of the College of Teachers, London; Fellow and Life Member of AFTRA Fellow of the Nigerian Institute of Management; Member of the Nigerian Academy of Education; Member of the Association of Sociologists of Education of Nigeria; Member of the British Sociological Association; among others. 